\title{
Corn and Soybean Productivity in Succession to Family Coverage Plants Poaceae and Fabaceae
}

\author{
Marcos Cesar Mottin \\ Center of Agrarian Sciences, Western Paraná State University- Unioeste \\ Street Pernambuco, 1777 - Center, Zip Code: 85960-000, Marechal Cândido Rondon - \\ PR, Brazil. \\ E-mail: marcos.c.mottin@ hotmail.com
}

Edleusa Pereira Seidel (Corresponding of author)

Center of Agrarian Sciences, Western Paraná State University- Unioeste

Street Pernambuco, 1777 - Center, Zip Code: 85960-000, Marechal Cândido Rondon PR, Brazil

E-mail: edleusa.seidel@unioeste.br

Emerson Fey

Center of Agrarian Sciences, Western Paraná State University- Unioeste

Street Pernambuco, 1777 - Center, Zip Code: 85960-000, Marechal Cândido Rondon PR, Brazil

E-mail: emerson.fey@unioeste.br

Jaqueline Vanelli

Center of Agrarian Sciences, Western Paraná State University- Unioeste

Street Pernambuco, 1777 - Center, Zip Code: 85960-000, Marechal Cândido Rondon PR, Brazil

E-mail: jaqueline.vnll@gmail.com

André Luiz Alves

Center of Agrarian Sciences, Western Paraná State University- Unioeste Street Pernambuco, 1777 - Center, Zip Code: 85960-000, Marechal Cândido Rondon - 
PR, Brazil

E-mail: andre_luiz.alves@ outlook.com

\author{
Monica Carolina Sustakowski (Corresponding author) \\ Center of Agrarian Sciences, Western Paraná State University- Unioeste
}

Street Pernambuco, 1777 - Center, Zip Code: 85960-000, Marechal Cândido Rondon PR, Brazil

E-mail: monica_sustakowski@hotmail.com

\author{
Received: May 24, 2021 Accepted: June 17, 2021 Published: June 22, 2021 \\ doi:10.5296/jas.v9i3.18665 \\ URL: https://doi.org/10.5296/jas.v9i3.18665
}

\begin{abstract}
The use of soil cover plants has varied effects on crops grown in succession, depending on the cover plant used. The objective of this study was to evaluate the effect of soil cover plants from the Poaceae and Fabaceae families grown in the autumn and winter on yields of corn and soybean grown in succession. The experiment was carried out for two years and the experimental design used was randomized block design, with six replications. Both in the first year and the second, the plots consisted of the cultivation of corn or soybeans on the different biomasses of four cover crops cultivated in autumn and winter intercropped with corn. The cover crops were two Poaceae plants (black oats and brachiaria) and two Fabaceae plants (forage pea and white lupine). The production and productivity parameters of summer corn and soybean commercial crops were evaluated Cover plants of the Poaceae (black oat and brachiaria) and Fabacea (pea and white lupine) families intercropped with corn grown in autumn-winter did not affect their yield components and yield; as well as the productivity of soybeans in succession. According to the results of this work, the cultivation of black oat, brachiaria, forage pea and lupine increases the number of species that the farmer can cultivate intercropped with corn, favoring the crop rotation system in no-till.
\end{abstract}

Keywords: sustainable agriculture, No-till, crop rotation, green manure

\title{
1. Introduction
}

Corn and soybean are considered to be amongst the most important crops in the world with 1525.38 billion tons (Mendes, 2020). Brazil is the third largest corn producer with a production of more than 84.7 million tons (CONAB, 2015) and the second largest soybean producer at over 96.2 million tons (USDA, 2015).

To increase the productivity of agricultural areas there are necessity to improve in soil 
management. The main technology to increase soil quality is the no-till system (Bai et al., 2018). Other measures are: the adoption of crop rotation, the cultivation of cover crops, in intercropped or in succession with commercial crops (Steiner et al., 2011; Wutke et al., 2014; Carvalho et al., 2015). the increase in organic matter content (Giongo et al., 2011; Souza et al., 2014) and the adoption of conservation practices. These measures can reduce the impacts of conventional farming, which tend to increase soil degradation

There are countless advantages of using the rotation system and/or crop succession, among them the stability of grain yield from crops of economic interest, the breakdown of the cycle of disease and pests (Silva et al., 2007), and reduction of weed infestation (Franchini et al., 2011). Other advantages are nutrient cycling, with the diversified use of species with different root systems, maintenance or improvement of soil properties (Lopes et al., 2007), reduction in soil temperature variation (Boer et al., 2008) and evapotranspiration (Giongo et al., 2011), and greater soil protection against erosion (Lanzanova et al., 2010).

In this context, several hedging plants have been used and researched as soil cover as part of a rotation and/or succession system (Costa et al., 2014). Plants of the Poaceae family have great potential for use in rotation, as they have a rooting system fasciculated denser, with greater contact with soil particles (Brancalião et al., 2015), which contributes to soil aggregation. In addition, they present a large contribution of biomass on the surface and persistence in soil cover due to the high carbon/nitrogen ratio, thus reducing the decomposition process (Calvo et al., 2010).

Plants of the Fabaceae family present a carbon/lower nitrogen and are more effective in a short time due favouring the rapid decomposition (Brancalião et al., 2015), providing a large volume of biomass for decomposition. However, the amount of nutrients released by Poaceae may be equal or even superior to those added by Fabaceae plants (Doneda et al., 2012).

It is worth mentioning that the use of soil cover plants provides effects on crop behavior when grown in succession (Matoso et al., 2015), and these effects vary as a function of each cover plan used (Cardoso et al., 2014). In this context, the objective of this study was to evaluate the effect of soil cover plants from the Poaceae and Fabaceae families grown in the autumn and winter on yields of corn and soybean grown in succession.

\section{Material and Methods}

\subsection{Location, Climate and Soil of the Experimental Area}

The work was carried out on the private agricultural property Água Vitória in the municipality of Tupãssi - PR, located at the geographic coordinates $24^{\circ} 38^{\prime} 18.72^{\prime \prime}$ of south latitude and $53^{\circ} 34^{\prime} 33.49^{\prime \prime}$ of west longitude, at 488 meters of altitude in relation to sea level.

According to Köppen's climate classification, the region's climate is of the humid subtropical mesothermal (Cfa) type, with hot summers, with average temperatures above $22^{\circ} \mathrm{C}$ and winters with average temperatures below $18^{\circ} \mathrm{C}$ and an average annual rainfall of $1600-1800$ millimeters (CAVIGLIONE, 2000).

The soil of the experimental unit is classified according to Santos et al. (2013) as typical Red 


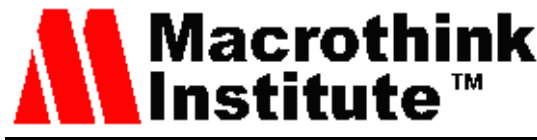

Eutrophic Oxisol, with a very clayey texture and smooth undulating relief. Prior to the experiment, the area had been cultivated with oats in the winter period and corn in succession in the summer.

Prior to the implementation of the experiment, deformed soil samples were collected at depths of $0-0.20 \mathrm{~m}$ for the determination of chemical and granulometric characteristics. Chemical analysis was performed according to the methodology of Raij et al. (2001). Results were as follows: $\mathrm{pH}\left(\mathrm{CaCl}_{2}\right)=6.05 ; \mathrm{MO}=24.61 \mathrm{~g} \mathrm{dm}^{-3} \mathrm{P}=2.36 \mathrm{mg} \mathrm{dm}^{-3} ; \mathrm{Ca}^{2+}=6.61 \mathrm{cmol}_{\mathrm{c}}$ $\mathrm{dm}^{-3} ; \mathrm{Mg}^{2+}=1.77 \mathrm{cmol}_{\mathrm{c}} \mathrm{dm}^{-3} ; \mathrm{K}^{+}=0.25 \mathrm{cmol}_{\mathrm{c}} \mathrm{dm}^{-3} ; \mathrm{Al}^{3+}=0.0 \mathrm{cmol}_{\mathrm{c}} \mathrm{dm}^{-3} ; \mathrm{H}^{+}+\mathrm{Al}^{3+}=2.54$ $\mathrm{cmol}_{\mathrm{c}} \mathrm{dm}^{-3}$ and $\mathrm{V}(\%)=77.26$. In the granulometric analysis, the soil presented $763 \mathrm{~g} \mathrm{~kg}^{-1}$ clay, $136 \mathrm{~g} \mathrm{~kg}^{-1}$ silt and $101 \mathrm{~g} \mathrm{~kg}^{-1}$ sand.

\subsection{Experimental Design}

The experiment was carried out for two years and the experimental design used was randomized block design, with six replications. Both in the first year and the second, the plots consisted of the cultivation of corn or soybeans on the different biomasses of four cover crops cultivated in autumn and winter; two Poaceae plants (black oats $\left(\mathrm{T}_{1}\right)$ and brachiaria $\left(\mathrm{T}_{2}\right)$ and two Fabaceae plants (pea forage $\left(\mathrm{T}_{3}\right)$ and white lupine $\left(\mathrm{T}_{4}\right)$ ). Each plot was $10.0 \mathrm{~m}$ long and $5.40 \mathrm{~m}$ wide, totaling $54 \mathrm{~m}^{2}$. The useful area of the plot was determined by discarding $0.50 \mathrm{~m}$ and $0.45 \mathrm{~m}$ at each end and each side, respectively, totaling $40.5 \mathrm{~m}^{2}$.

\subsection{Conducting the Experiment}

Sowing of crops in autumn and winter was mechanically performed with a seeder share on 09/05/2014, using $70 \mathrm{~kg} \mathrm{ha}^{-1}$ of oat (Avena strigosa S.) cultivar Iapar 61 Ibiporã; $8 \mathrm{~kg} \mathrm{ha}^{-1}$ brachiaria (Urochloa ruziziensis) with cultural value of $73.06 ; 60 \mathrm{~kg} \mathrm{ha}^{-1}$ of pea (Pisum sativum L.) cultivar Iapar 83 and $50 \mathrm{~kg} \mathrm{ha}^{-1}$ of white lupine (Lupinus albus L.). The spacing used was $0.20 \mathrm{~m}$ to $0.40 \mathrm{~m}$ for Poaceae and Fabaceae. No base and/or cover fertiliser was used.

At 120 days after sowing, plant cover was managed by using $3 \mathrm{~kg} \mathrm{ha}^{-1}$ of glyphosate acid equivalent. Planting of commercial summer crops was performed mechanically and harvesting manually. The corn crop was sown after the management of the cover plants (25 days) using the variety Capixaba Incaper 203 with between-row spacing of $0.70 \mathrm{~m}$ and 5.1 seeds/linear meter. Basic fertilizer application of $279 \mathrm{~kg} \mathrm{ha}^{-1}$ of a 10-15-15 formulation, with $70 \mathrm{~kg} \mathrm{ha}^{-1}$ of nitrogen, was carried out when plants were in the vegetative stage V3 (third developed sheet).

Sowing of the soybean crop was carried out in December, due to the drought in the region. The cultivar used was Vtop 1059 Syngenta at a spacing of $0.50 \mathrm{~m}$ between rows, with 17 seeds/linear meter. Basic fertilizer application was at the rate of $268 \mathrm{~kg} \mathrm{ha}^{-1}$ with a 2-20-18 formulation. The control of weeds and insects was carried out as necessary, based on the technical recommendations of Embrapa (2011). For the soybean crop, preventive control of fungal diseases was carried out.

\subsection{Evaluation of Agronomic Characteristics and Productivity}


At the time of the corn harvest (18-25\% moisture content of the grain) 10 corn ears were collected at random in the useful area to assess the ear length (tape), measuring the base of the tip of the spike; Diameter of the pin (caliper graduated in centimeters), determined in the medial part of the spike; number of rows of grain per ear (counting rows of grain of each ear, individually); mass of 1000 grains (average of 8 subsamples of 100 grains in precision scale, corrected for $13 \%$ of humidity), thus estimating the mass of 1000 grains; and productivity (mass of grain produced in the portion corrected to $13 \%$ moisture estimating productivity for $\mathrm{Mg} \mathrm{ha}^{-1}$ )

The soybeans were harvested with 14-16\% moisture content of the grain. Before the harvest, 20 plants per plot were randomly collected and sent to the laboratory for evaluation. The following parameters were determined: number of pods per plant; number of grains per pod; number of pods with 1, 2 or 3 grains; and number of grains per plant. The mass of 1000 grains was also determined, based on the mean of the mass of eight subsamples of 100 grains using a precision scale and corrected for $13 \%$ humidity. Productivity was calculated as the mass of grain produced in the portion corrected to $13 \%$ moisture and expressed as $\mathrm{Mg} \mathrm{ha}^{-1}$.

\subsection{Statistical Analysis}

The data obtained were tabulated and submitted to analysis of variance considering a level of significance of $5 \%$ for the F-test. When significant, the means were compared by the Scheffe test at 5\% probability, using the statistical software Sisvar (Ferreira, 2011). The contrasts used in the comparison of treatment means the ground cover plants grown in autumn and winter by Scheffe test were: $\mathrm{C}_{1}$ : Comparison of households $\left(+1 \mathrm{~T}_{1}+1 \mathrm{~T}_{2}-1 \mathrm{~T}_{3}-1 \mathrm{~T}_{4}\right) ; \mathrm{C}_{2}$ : Comparison within the Poaceae family $\left(-1 \mathrm{~T}_{1}+1 \mathrm{~T}_{2}\right)$ and $\mathrm{C}_{3}$ : Comparison within the Fabaceae family $\left(-1 \mathrm{~T}_{3}\right.$ $\left.+1 \mathrm{~T}_{4}\right)$.

\section{Results and Discussion}

\subsection{Corn Cultivation}

Table 1 shows the mean results for the production and yield components of the corn crop grown in succession to the soil cover plants. Based on Table 2, it was found that there was no effect ( $\mathrm{p}<0.05$ ) of cover crops grown in the autumn and winter on ear length, ear diameter, number of rows of grains, mass of 1000 grains, yield and number of plants per hectare of corn grown in succession. 
Table 1 - Average results for the parameters of production and productivity ofcorn grains, according to cultivation in succession to cover crops

\begin{tabular}{|c|c|c|c|c|c|c|}
\hline $\begin{array}{l}\text { Coverage } \\
\text { plants }\end{array}$ & $\begin{array}{c}\text { Ear } \\
\text { length }\end{array}$ & $\begin{array}{c}\text { Ear } \\
\text { diameter } \\
\mathrm{cm}-\end{array}$ & $\begin{array}{l}\text { Number } \\
\text { of rows } \\
\text { of grains }\end{array}$ & $\begin{array}{c}1000 \\
\text { grain } \\
\text { mass } \\
\mathrm{g}\end{array}$ & $\begin{array}{l}\text { Productivity } \\
\mathrm{Mg} \mathrm{ha}^{-1}\end{array}$ & $\begin{array}{c}\text { Number of } \\
\text { plants per } \\
\text { hectare }\end{array}$ \\
\hline & \multicolumn{6}{|c|}{ Family Poaceae } \\
\hline Oats $\left(\mathrm{T}_{1}\right)$ & 17.83 & 50.33 & 16.0 & 352.17 & 7.43 & 73511 \\
\hline Brachiaria $\left(\mathrm{T}_{2}\right)$ & 17.67 & 50.0 & 16.0 & 355.33 & 7.60 & 74404 \\
\hline Average & 17.75 & 50.17 & 16.0 & 353.75 & 7.51 & 73958 \\
\hline & \multicolumn{6}{|c|}{ Family Fabaceae } \\
\hline Peas $\left(\mathrm{T}_{3}\right)$ & 19.0 & 50.33 & 16.0 & 354.50 & 8.08 & 71428 \\
\hline Lupine $\left(\mathrm{T}_{4}\right)$ & 17.67 & 49.17 & 16.0 & 364.50 & 6.95 & 73214 \\
\hline Average & 18.33 & 49.75 & 16.0 & 359.50 & 7.51 & 72321 \\
\hline $\mathrm{F}$ (treatments) & $2.36^{\mathrm{NS}}$ & $0.58^{\mathrm{NS}}$ & $0.81^{\mathrm{NS}}$ & $1.83^{\mathrm{NS}}$ & $0.70^{\mathrm{NS}}$ & $2.05^{\mathrm{NS}}$ \\
\hline $\mathrm{CV}(\%)$ & 5.69 & 3.55 & 5.24 & 2.75 & 18.15 & 2.92 \\
\hline
\end{tabular}

*: Significant by the Scheffé test at 5\% probability, within each parameter evaluated; NS: Not significant by the Scheffé test at $5 \%$ probability, within each parameter evaluated.

Table 2 - Values of contrasts for the parameters of production and productivity of corn grain as a function of growing in succession to cover plants

\begin{tabular}{ccccccc}
\hline $\begin{array}{c}\text { Coverage } \\
\text { plants }\end{array}$ & $\begin{array}{c}\text { Ear } \\
\text { length }\end{array}$ & $\begin{array}{c}\text { Ear } \\
\text { diameter }\end{array}$ & $\begin{array}{c}\text { Number } \\
\text { of rows } \\
\text { of grains }\end{array}$ & $\begin{array}{c}1000 \\
\text { grain } \\
\text { mass } \\
\mathrm{g}\end{array}$ & Productivity & $\begin{array}{c}\text { Number of } \\
\text { plants per } \\
\text { hectare }\end{array}$ \\
\hline $\mathrm{C}_{1}$ & $-0.58^{\mathrm{NS}}$ & $0.42^{\mathrm{NS}}$ & $0.0^{\mathrm{NS}}$ & $-5.75^{\mathrm{NS}}$ & $0.00^{\mathrm{NS}}$ & $1637^{\mathrm{NS}}$ \\
$\mathrm{C}_{2}$ & $-0.16^{\mathrm{NS}}$ & $-0.33^{\mathrm{NS}}$ & $0.0^{\mathrm{NS}}$ & $3.16^{\mathrm{NS}}$ & $0.17^{\mathrm{NS}}$ & $893^{\mathrm{NS}}$ \\
$\mathrm{C}_{3}$ & $-1.33^{\mathrm{NS}}$ & $-1.16^{\mathrm{NS}}$ & $0.0^{\mathrm{NS}}$ & $10.0^{\mathrm{NS}}$ & $-1.13^{\mathrm{NS}}$ & $1786^{\mathrm{NS}}$ \\
\hline
\end{tabular}

Legend: $\mathrm{C}_{1}:\left(+1 \mathrm{~T}_{1}+1 \mathrm{~T}_{2}-1 \mathrm{~T}_{3}-1 \mathrm{~T}_{4}\right) ; \mathrm{C}_{2}:\left(-1 \mathrm{~T}_{1}+1 \mathrm{~T}_{2}\right) \mathrm{e} ; \mathrm{C}_{3}:\left(-1 \mathrm{~T}_{3}+1 \mathrm{~T}_{4}\right)$.

*: Significant by the Scheffé test at 5\% probability, within each parameter evaluated; NS: Not significant by the Scheffé test at 5\% probability, within each parameter evaluated.

The components of corn crop production (length of ear, ear diameter and number of rows of grains) were similar to those reported by Lázaro et al. (2013). It is worth mentioning that ear length, ear diameter and grain density is characteristics that determine the yield potential of corn, with diameter being directly related to the number of grain rows per spike (Ohland et al., 2005). The value for the mass of 1000 grains obtained in this study (356 g), regardless of the predecessor cultivated, was higher than the average value reported by Debiasi et al. (2010), which was $304 \mathrm{~g}$. This feature is influenced by genotype, nutrient availability and climatic conditions during grain filling stages (Ohland et al., 2005).

The population of plants per hectare in corn ranged from 71000 to 74000 plants ha ${ }^{-1}$, getting close to the value for the highest net revenue, namely 80000 plants ha $^{-1}$ (Primaz et al., 2015). However, it should be remembered that the ideal population depends on the cultivar, soil 
fertility, water availability and sowing time (Amaral Filho et al., 2005).

The corn yield (7.51 $\mathrm{Mg} \mathrm{ha}^{-1}$ ) regardless of the family of the soil cover crop used in the autumn and winter cover crops was higher than the national average of $6.56 \mathrm{Mg} \mathrm{ha} \mathrm{h}^{-1}$ (CONAB, 2015) and, on average, exceeded national productivity by $14.48 \%$ (Table 1). However, this productivity was below the average value for West Paraná $\left(9.4 \mathrm{Mg} \mathrm{ha}^{-1}\right)$. This is probably because this variety (Incaper 203) does not have high yield potential and is usually grown in organic systems. These results corroborate those of Martins and Rosa Junior (2005) who evaluated this cultivation under similar conditions.

The results reveal that not all the plants from the Fabaceae family predating the corn are able to add nitrogen to the system, providing the highest grain yield when compared to Poaceae family. However, contrasting results were reported by Carvalho et al. (2015) when evaluating productivity in two consecutive years under cultivar brachiaria, millet, sorghum, wheat, crotalaria, wild beans, pigeon pea, mucuna, forage turnip and spontaneous vegetation. In the first year, showed that corn crop yields were similar, but in the second year, found significant differences $(p>0.05)$ between some plants of different families and also within each of the plant families. This is related to the more rapid decomposition of the vegetal residues of some plants, being influenced by the accumulated amount of dry mass, nitrogen (Carvalho et al., 2015) and lignin (Carvalho et al., 2013).

\subsection{Soybean Cultivation}

The average results for the production of components and soybean yield in succession with the different hedge plants are shown in Table 3. Based on Table 4, it was found that there was no effect of different families of plants used and neither among the species. The results are similar to those of Carvalho et al. (2004) and Santos et al. (2006), who did not find differences in the production components between different crop rotation/succession systems during a five-year period.

The average yield of $2.66 \mathrm{Mg} \mathrm{ha}^{-1}$ (Table 3) was below the national average of about $3.0 \mathrm{Mg}$ $\mathrm{ha}^{-1}$, a difference in yield of approximately $13 \%$. This occurred due to the sowing time of the soybean crop, which affected the vegetative and productive performance of the crop (Cruz et al., 2010).

The sowing time is considered to be a factor that influences the yield of the soybean crop (Embrapa, 2003). Late sowing increases plant exposure to more severe pest attack (Motta et al., 2002) and to variation in climatic factors (Garcia et al., 2007). These results are corroborated by Barbosa et al. (2011) and Sanchez et al. (2014), who did not find significant differences for soybean cultivation in succession using different cover crops.

The population of soybean plants did not show significant effects of the different families and species of cover crops. The population was in the range 192000 to 215000 plants ha $^{-1}$, within the accepted range for soybean crops of 20000 to $500000 \mathrm{ha}^{-1}$ (Embrapa, 2011).

Plant populations higher than recommended levels increase seed expenditure, can cause bedding and do not provide increases in productivity. Plant populations below the 
recommended levels favor the development of weeds and can result in highly branched plants and reduced plant height, which increases losses at harvest (Vazquez et al., 2008). It is worth mentioning that the low population of plants did not significantly interfere with the productivity of the soybean crop, since it was able to withstand large population reductions (Vazquez et al., 2008).

Yield obtained with both corn and soybean crops demonstrated that only one crop cycle of soil cover crops (oats, brachiaria, forage peas and lupine) did not directly influence the increase or reduction of the productive potential of the crops in succession. This demonstrated that the cover crops evaluated in the present study can be included in a system of rotation and/or succession of crops without losses in productivity, since grain yield did not show significant differences.

Table 3 - Average results for the parameters of production and productivity of com grains, according to cultivation in succession to cover crops

\begin{tabular}{|c|c|c|c|c|c|c|c|c|c|}
\hline \multirow[t]{2}{*}{ Coverage plants } & \multirow[t]{2}{*}{$\begin{array}{l}\text { Number } \\
\text { of pods } \\
\text { per plant }\end{array}$} & \multirow[t]{2}{*}{$\begin{array}{c}\text { Number of } \\
\text { grains per } \\
\text { pod }\end{array}$} & \multicolumn{3}{|c|}{ Number of pods with 1,2 or 3 grains } & \multirow[t]{2}{*}{$\begin{array}{c}\text { Number of } \\
\text { grains per } \\
\text { plant }\end{array}$} & \multirow{2}{*}{$\begin{array}{c}1000 \text { grain } \\
\text { mass }\end{array}$} & \multirow{2}{*}{$\begin{array}{l}\text { Productivity } \\
-\mathrm{Mg} \mathrm{ha}^{-1}-\end{array}$} & \multirow[t]{2}{*}{$\begin{array}{c}\text { Number of } \\
\text { plants per } \\
\text { hectare }\end{array}$} \\
\hline & & & $-1-$ & $-2-$ & $\begin{array}{c}-3- \\
\text { Family } P o c\end{array}$ & & & & \\
\hline Oats $\left(\mathrm{T}_{1}\right)$ & 52.0 & 2.0 & 21.0 & 21.0 & 10.0 & 104 & 145.0 & 2.45 & 215416 \\
\hline $\operatorname{Brachiaria}\left(\mathrm{T}_{2}\right)$ & 64.0 & 2.0 & 23.0 & 27.0 & 14.0 & 128 & 144.83 & 2.74 & 186250 \\
\hline Average & 58.0 & 2.0 & 22.0 & 24.0 & 12.0 & 116 & 144.92 & 2.60 & 200833 \\
\hline & & & & & Family Fab & aceae & & & \\
\hline $\operatorname{Peas}\left(\mathrm{T}_{3}\right)$ & 63.0 & 2.0 & 24.0 & 27.0 & 12.0 & 126 & 137.67 & 2.72 & 192916 \\
\hline Lupine $\left(\mathrm{T}_{4}\right)$ & 54.0 & 2.0 & 20.0 & 24.0 & 10.0 & 108 & 136.33 & 2.73 & 210833 \\
\hline Average & 58.0 & 2.0 & 22.0 & 25.0 & 11.0 & 116 & 137.0 & 2.72 & 201875 \\
\hline $\mathrm{F}$ (treatments) & $4.01^{\mathrm{NS}}$ & $1.09^{\mathrm{NS}}$ & $1.68^{\mathrm{NS}}$ & $2.84^{\mathrm{NS}}$ & $3.48^{\mathrm{NS}}$ & $3.28^{\mathrm{NS}}$ & $1.04^{\mathrm{NS}}$ & $0.28^{\mathrm{NS}}$ & $1.67^{\mathrm{TS}}$ \\
\hline $\mathrm{CV}(\%)$ & 12.86 & 3.64 & 13.60 & 16.45 & 18.55 & 14.45 & 7.86 & 23.94 & 13.18 \\
\hline
\end{tabular}

Table 4. Values of contrasts for theproduction parameters and productivity of soybean grain as a function of growing in succession to cover plants

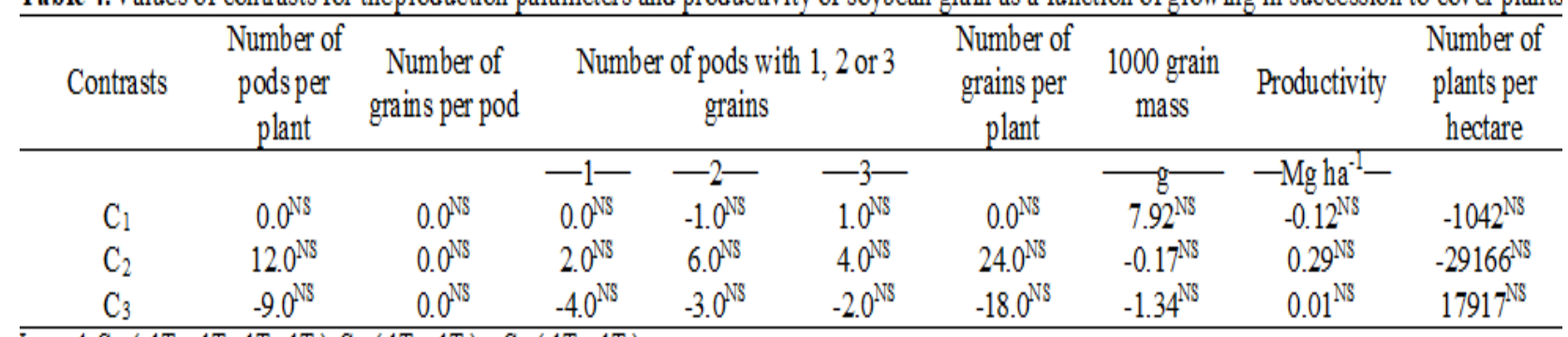

Legend: $\mathrm{C}_{1}:\left(+1 \mathrm{~T}_{1}+1 \mathrm{~T}_{2}-1 \mathrm{~T}_{3}-1 \mathrm{~T}_{4}\right) ; \mathrm{C}_{2}:\left(-1 \mathrm{~T}_{1}+1 \mathrm{~T}_{2}\right) \mathrm{e}_{3} \mathrm{C}_{3}:\left(-1 \mathrm{~T}_{3}+1 \mathrm{~T}_{4}\right)$.

*: Sigrificant by the Scheffe test at $5 \%$ probability, within each parameter evaluated; NS: Not significant by the Scheffe test at $5 \%$ probability, within each parameter

\section{Conclusion}

Cover plants of the Poaceae (black oat and brachiaria) and Fabacea (pea and white lupine) families intercropped with corn grown in autumn-winter did not affect their yield components and yield; as well as the productivity of soybeans in succession. 
According to the results of this work, the cultivation of black oat, brachiaria, forage pea and lupine increases the number of species that the farmer can cultivate intercropped with corn, favoring the crop rotation system in no-till.

\section{Acknowledgement and Sponsoring Information}

The authors would like to thank the State University of Western Paraná for their support in the development of the research. To the Personnel Improvement Coordination Higher Education by scholarships provide of studies to the authors.

\section{References}

Amaral Filho, J. P. R., Fornasieri Filho, D., Farinelli, R., \& Barbosa, J. C. (2005). Row spacing, population density and nitrogen fertilization in corn. Revista Brasileira de Ciência do Solo. 29(3), 467-473. https://doi.org/10.1590/S0100-06832005000300017

Bai, Z., Caspari, T., Gonzales, M. R. et al. (2018). Effects of agricultural management practices on soil quality: A review of long-term experiments for Europe and China. Agriculture, Ecosystems \& Environment. 265, 1-7. https://doi.org/10.1016/j.agee.2018.05.028

Barbosa, C. E. M., Lazarini, E., Picoli, P. R. F., \& Ferrari, S. (2011). Cover plants in the dry winter region for direct soybean seeding. Scientific. 39(1/2), 52-64.

Boer, C. A., Assis, R. L., Silva, G. P., Braz, A. J. B. P., Barroso, A. L. L., Filho, A. C., \& Pires, F. R. (2008). Biomass, decomposition and soil cover caused by cultural residues of three plant species in the Center-West region of Brazil. Revista Brasileira de Ciência do Solo. 32, 843-851. https://doi.org/10.1590/S0100-06832008000200038

Brancalião, S. R., Aguiar A. T. E, Brancalião, E. M., Limonta, C. R., Rossi, C. E., \& Cristovão, N. N. (2015). Productivity and composition of soybean grains after the nitrogen supply with the use of cover crops under no-tillage system. Nucleus. 12, 69-76. https://doi.org/10.3738/1982.2278.1001

Calvo, C. L., Foloni, J. S. S., \& Brancalião, S. R. (2010). Phytomass productivity and C/N ratio of monocultures and pigeon pea, millet and sorghum consortia in three cutting seasons. Bragantia. 69, 77-86. https://doi.org/10.1590/S0006-87052010000100011

Cardoso, R. A., Bento, A. S., Moreski, H. M., \& Gasparotto, F. (2014). Influence of green manuring on soil physical and biological properties and yield of soybean crop. Semina: Biological Sciences Health. 35(2), 51-60. https://doi.org/10.5433/1679-0367.2014v35n2p51

Carvalho, A. M., Coser, T. R., Rein, T. A., Dantas, R. A., Silva, R. R., \& Souza, K. W. (2015). Management of cover crops in flowering and physiological maturation and their effect on corn productivity. Pesq Agropec Bras. 50(7), 551-561. https://doi.org/10.1590/S0100-204X2015000700005

Carvalho, A. M., Coelho, M. C., Dantas, R. A., Fonseca, O. P., Guimarães Júnior, R., \& Figueiredo, D. C. (2013). Chemical composition of cover plants and its effect on corn yield in 
no-tillage systems in the Brazilian savanna. Crop and Pasture Science. 63(11/12), 1075-1081. https://doi.org/10.1071/CP12272

Carvalho, M. A. C, Athayde, M. L. F., Soratto, R. P., Alves, M. C., \& Arf, O. (2004). Soya in succession to green manures in no-tillage system and conventional in cerrado soil. Pesquisa Agropecuária Brasileira. 39, 1141-1148. https://doi.org/10.1590/S0100-204X2004001100013

Caviglione, J. H., Kiihl, L. R. B., Caramori, P. H., \& Oliveira ,D. (2000). Climate Parana Letters. Londrina. Agronomic Institute of Paraná (IAPAR). CD-ROM.

CONAB (2015). Monitoring of the Brazilian grain harvest. 2014/2015 crop year. 2(12). Twelfth survey/September 2015. Brasília: National Supply Company. p. 1-134.

Costa, N. R., Andreotti, M., Buzetti, S., Lopes, K. S. M., Santos, F. G., \& Pariz, C. M. (2014). Macronutrient accumulation and decomposition of the brachiaria straw due to nitrogen fertilization during and after intercropping with corn crop. Revista Brasileira de Ciência do Solo. 38, 1223-1233. https://doi.org/10.1590/S0100-06832014000400019

Cruz, T. V., Peixoto, C. P., \& Martins, M. C. (2010). Growth and productivity of soybean at different sowing times in western Bahia. Scientia Agraria. 11, 033-042. https://doi.org/10.5380/rsa.v11i1.15941

Debiasi, H., Levien, R., Trein, C. R., Conte, O., \& Kamimura, K. M. (2010). Yield of soybeans corn after winter cover and mechanical soil unpacking. Pesquisa Agropecuária Brasileira. 45. 603-612. https://doi.org/10.1590/S0100-204X2010000600010

Doneda, A., Aita, C., Giacomini, S. J., Miola, E. C. C., Giacomini, D. A., Schirmann, J., \& Gonzatto, R. (2012). Phytomass and decomposition of residues of pure and consortium cover crops. Revista Brasileira de Ciência do Solo. 36, 1714-1723. https://doi.org/10.1590/S0100-06832012000600005

Embrapa (2003). Technologies and soybean production - Paraná 2004. $1^{\text {st }}$ ed. Londrina: Brazilian Agricultural Research Corporation (Embrapa). 218 p.

Embrapa (2011). Technologies and soybean production - central Brazil in 2012 and 2013. $1^{\text {st }}$ ed. Londrina: Brazilian Agricultural Research Corporation (Embrapa). 261 p.

Ferreira, D. F. (2011). Sisvar: A computer statistical analysis system. Science and Agrotecnologia. 35, 1039-1042. https://doi.org/10.1590/S1413-70542011000600001

Franchini, J. C., Costa, J. M., Debiase, H., \& Towers, A. N. D. (2011). Importance of crop rotation for sustainable agricultural production in Paraná. $1^{\text {st }}$ ed. Documents 327. Londrina: Brazilian Agricultural Research Corporation (Embrapa Soja). 52 p.

Garcia, A., Pipol, A. E., Lopes, I. O. N., \& Portugal, F. A. F. (2007). Instalção soybean crop: time, cultivars, spacing and plant population. $1^{\text {st }}$ ed. Technical Circular 51. Londrina: Brazilian Agricultural Research Corporation (Embrapa Soja). 12 p.

Giongo, V., Mendes, A. M. S, Cunha, T. J. F., \& Galvão, S. R. S. (2011). Decomposition and release of nutrients from vegetable cocktails for use in the Brazilian semiarid region. Revista 
Ciência Agronomica, 42(3), 611-618. https://doi.org/10.1590/S1806-66902011000300006

Lanzanova, M. E., Eltz, F. L. F., Nicoloso, R. S., Amado, T. J. C., Reinert, D. J., \& Rocha, M. R. (2010). Physical attributes of an Argisol in long - term cropping systems under no-tillage. Revista Brasileira de Ciência do Solo. 34, 1333-1342. https://doi.org/10.1590/S0100-06832010000400030

Lázaro R. L., Costa A. C. T., Silva K. F., Sarto M. V. M., \& Duarte Júnior J. B. (2013). Productivity of corn grown in succession to green manure. Pesquisa Agropecuária Tropical. 43(1), 10-17. https://doi.org/10.1590/S1983-40632013000100008

Lopes, R. A. P, Nóbrega, L. H. P., Uribe-Opazo, M. A., Prior, M., \& Pereira, J. O. (2007). Physical properties of typical Red Dystroferric Oxisol under management systems in the soybean-corn succession in the three-year period. Acta Scientiarum Agronomy. 29, 721-727. https://doi.org/10.4025/actasciagron.v29i5.755

Martins, R. M. G., \& Rosa Junior, E. J. (2008). Culturas antecessoras influenciando a cultura de milho e os atributos do solo no sistema de plantio direto. Acta Scientiarum. Agronomy, 27(2), 225-232. https://doi.org/10.4025/actasciagron.v27i2.1485

Matoso, A. O., Souza, L. C. F., Andrade, L. H. L., Pedroso, F. F., \& Costa, N. R. (2015). Agronomic performance of corn crop under different cover crops in the cerrado. Tecnologia \& Ciência Agropecuaria, 9, 29-34.

Mendes, C. (2020). USDA estimates the production of BR 2019/20 soybeans at 126 million tons and reduces the new US crop. Notícias Agrícolas https://www.noticiasagricolas.com.br/noticias/usda/263565-usda-estima-producao-de-soja-20 1920-do-br-em-126-mi-de-t-e-reduz-safra-nova-dos-eua.html\#.YMnzJ6hKjIU. Acessed on Oct.2020.

Motta, I. S., Braccini, A. L., Scapim, C. A., Inoue, M. H., Ávila, M. R., \& Braccini, M. C. L. (2002). Sowing time in five soybean cultivars. II. Effect on the physiological quality of the $\begin{array}{llll}\text { seeds. Acta } & \text { Scientiarum: } & \text { Agronomy. } & \text { 1281-1286. }\end{array}$ https://doi.org/10.4025/actasciagron.v24i0.2291

Ohland, R. A. A., Souza, L. C. F., Hernani, L. C., Marchetti, M. E., \& Gonçalves, M. C. (2005). Soil cover crops and corn fertilization in no-tillage. Ciência Agrotecnica. 29, 538-544. https://doi.org/10.1590/S1413-70542005000300005

Primaz, E, Balestrin, A. L., Conte, C. S., Junges, R. C., Camilo, M., \& Trevizan, K. (2015). Nitrogen yield and plant population in corn cultivar DKB 240 PRO. Journal of Agronomy and Veterinary Medicine IDEAU. 2, 001-012.

Raij, B. V., Andrade J. C., Cantarella H., \& Quaggio J. Á. (2001). Chemical analysis to evaluate the fertility of tropical soils. $1^{\text {st }}$ ed. Campinas: Agronomic Institute.

Sanchez, E., Maggi, M. F., Genú, A. M., \& Müller, M. M. L. (2014). Soil physical properties and soybean yield in succession to winter cover crops. Magistra. 26, 266-275. 


\section{Macrothink

Santos, H. G., Almeida, J. A., Oliveira, J. B., Lumbreras, J. F., Anjos, L. H. C., Coelho, M. R., Jacomine, P. K. T., Cunha, T. J. F, \& Oliveira, V. A. (2013). Brazilian System of Soil Classification. $3^{\text {rd }}$ ed. Brasilia: Brazilian Agricultural Research Corporation (EMBRAPA). $353 \mathrm{p}$.

Santos, H. P., Lhamby, J. C. B., \& Spera, S. T. (2006). Soya bean yield due to different soil management and crop rotation systems. Rural Science. 36, 21-29. https://doi.org/10.1590/S0103-84782006000100004

Silva, A. A., Silva, P. R. F., Argenta, G., Strieder, M. L., \& Rambo, L. (2007). Soil cover systems in winter and their effect on yield of corn grains in succession. Rural Science. 37, 928-935. https://doi.org/10.1590/S0103-84782007000400002

Souza, M. F. P., Dal Bem, E. A., Franco, A. A., Macedo, H. R., Nakao, A. H., \& Viotto, G. F. V. (2014). Chemical attributes of the soil and acid phosphatase of the bean plant due to the use of phosphate fertilizers and cover crops. Global Science and Technology. 7, 76-86. https://doi.org/10.14688/1984-3801/gst.v7n3p76-86

Steiner, F., Pivetta, L. A., Castoldi, G., Costa, M. S. S. M., \& Costa, L. A. M. (2011). Organic carbon and residual carbon of the soil under no-tillage system, submitted to different management. Revista Brasileira Ciência Agrária. 6, 401-408. https://doi.org/10.5039/agraria.v6i3a944

USDA (2015) World agricultural supply and demand estimates. Washington: United States Department of Agriculture. p. 1-40.

Vazquez, G. H., Carvalho, N. M., \& Borba, M. M. Z. (2008). Reduction in plant population on yield and physiological quality of soybean seed. Brazilian Journal of Seeds. 30, 001-011.

Wutke, E. B., Calegari, A., \& Wildner, L. P. (2014). Species of green manures and cover crops and recommendations for their use. In: Lima Filho OF, Ambrosano EJ, Rossi F, Carlos JAD (ed) Green manure and cover crops in Brazil: principles and practice. Brasília: EMBRAPA, 2014. v.1, chap.3, p.59-168.

\section{Copyright Disclaimer}

Copyright for this article is retained by the author(s), with first publication rights granted to the journal.

This is an open-access article distributed under the terms and conditions of the Creative Commons Attribution license (http://creativecommons.org/licenses/by/4.0/). 